\title{
Urgensi Pendekatan Multi dan Inter-disiplin Ilmu dalam Penanggulangan Bencana
}

Wignyo Adiyoso ${ }^{1}$

${ }^{1}$ Perencana Ahli Madya di Kementerian PPN/Bappenas RI

Korespondensi: wignyoa@yahoo.com

https://doi.org/10.47266/bwp.v4i2.104| halaman: 167-177

Dikirim: 23-08-2021 | Diterima: 01-09-2021 | Dipublikasikan: 20-09-2021

\begin{abstract}
Abstrak
The intensity and serious impact of disasters threaten human life, including in Indonesia. A series of natural disasters such as floods, landslides, earthquakes, and tsunamis in the past decade have claimed thousands of lives and damaged property and destroyed social and cultural structures. Current pandemic as non-natural disaster also shows that Covid-19 become among deadliest of disasters. With the unpredictable characteristics of disaster events (especially natural and pandemic), it is urgent to find a collaboration model for effective disaster management. As a concept, an approach and a method disaster management is not a monodisciplinary, but cross-disciplinary, whether it is multidisciplinary, interdisciplinary or transdisciplinary. Using a description and information analysis approach using secondary data through the literature review, this study discusses the link and contribution issues of disaster management. The results of the discussion show that apart from being multidisciplinary, disaster management is also interdisciplinary and transdisciplinary. In the disaster management cycle, there are important roles that differ between multidisciplinary, interdisciplinary, and transdisciplinary. This preliminary finding may be useful for researchers, policy makers, disaster managers and others to start cooperating in reducing disaster risk. A more comprehensive and in-depth study is needed to see the relationship between disaster management and related sciences for strengthening disaster management in the future.
\end{abstract}

Kata kunci: science, disaster, countermeasure, disciplinary, multidisciplinary 


\title{
Urgensi Pendekatan Multi dan Inter-disiplin Ilmu dalam Penanggulangan Bencana
}

\author{
Wignyo Adiyoso
}

\section{Pendahuluan}

Akhir-akhir ini, kejadian bencana banyak terjadi di belahan bumi termasuk Indonesia. Data Informasi Bencana Indonesia, Badan Nasional Penanggulangan Bencana (BNPB, 2019) mencatat dalam 10 (sepuluh) terakhir ini (2000-2019), telah terjadi 27.022 kali kejadian bencana alam. Belum lagi bencana non-alam seperti teknologi, transportasi, kurusuhan sosial dan pada saat ini pademi Covid-19. Dalam kurun waktu tersebut jumlah korban meninggal (dan hilang) mencapai 187.092 jiwa, luka-luka 372,254 jiwa, dan menderita serta mengungsi 48.931 .229 jiwa (BNPB, 2019). Dalam bencana tersebut, telah menghancurkan rumah sebanyak 1.067 .980 (berat), rusak sedang 132,721 dan rusak ringan 1.396.588. Belum lagi kerusakan terhadap fasilitas publik seperti kantor pemerintahan, kesehatan, pendidikan, peribadatan, dan infrastruktur penting lainnya.

Pada tahun 2019, dunia juga dikagetkan dengan pandemic Covid-19 yang pada saat artikel ini ditulis telah menginfeksi sekitar 207,784,507 orang dan menyebabkan 4,370,424 orang meninggal dunia (WHO, 2021). Bencana non alam ini meskipun dikatakan masih lebih kecil jumlah korban di banding Spanish Flu yang terjadi pada tahun 1918-1919 (Robinson, 2021), mungkin akan berdampak panjang karena adanya perkembangan varian virus. Sayangnya, menurut para ahli, tidak banyak dokumentasi yang menjelaskan dan merekam penyebaran dan cara penanganan Spanish Flu sehingga kita tidak memiliki lesson learned untuk mengantisipasi dan menangan Covid-19 dengan baik (Feehan \& Apostolopoulos, 2021).

Dengan ancaman yang lebih besar dan frekuensi makin tinggi, upaya untuk penanggulangan bencana terus dilakukan. Manajemen bencana menjadi isu sentral dalam bidang politik, ekonomi, kebijakan, masyarakat, akademisi dan lainnya. Peran ilmu pengetahuan dan penelitian dalam bencana memberikan kontribusi yang tidak sedikit. Ilmu dan teknologi sangat penting untuk implementasi strategi dan kebijakan untuk memitigasi risiko dan membangun ketangguhan terhadap bencana alam dan non-alam, terutama dalam 20 tahun terakhir ini (Aitsi-Selmi et al., 2015). Pengembangan ilmu dan penelitian tentang bencana juga terus berkembang. Namun demikian belum banyak diskusi yang membahas tentang peran ilmu pengetahuan dalam manajemen bencana.

Publik sudah terbiasa menggunakan istilah "manajemen bencana" yang merujuk pada suatu pendekatan, strategi, metode, prosedur serta penggambaran tentang tata cara penanggulangan bencana. Apakah manajemen bencana adalah suatu ilmu pegnetahuan? Atau bagian dari ilmu manajemen? Atau seberapa penting peran atau kontribusi disiplin ilmu dalam penanggulangan bencana? Penelitian multidisipliner, intradispsliner dan transdispliner telah mendapatkan perhatian besar melingkupi ilmu-ilmu, sains, sosial, dan teknik untuk menelaah dan memberikan solusi terhadap suatu persoalan (National Research Council, 2006). Penggunaan berbagai disiplin ilmu dalam penelitian kebencanaan juga menyadari bahwa masih adanya ketimpangan (gap) pengetahuan dan penelitian tentang kebencanaan. Tulisan ini adalah kajian awal yang menelaah kontribusi disiplin ilmu dalam 
penanggulangan bencana. Metode analisis deskriptif digunakan dalam artikel ini dengan menggunakan bahan-bahan literatur terutama praktek-praktek baik yang telah dilakukan (Bengtsson, 2016). Identifikasi tentang keterhubungan antara isitilah bencana dan disiplin ilmu digali menggunakan pendekatan bibliomterika untuk mendapatkan gambaran awal tentang potret keilmuan dalam konteks manajemen bencana. Selanjutnya visualisasi menggunakan Vosviewer.

\section{Disiplin Ilmu dalam Manajemen Bencana}

Sejarah manajemen penanggulangan bencana, menurut Coppola (Damon P. Coppola, 2017) dapat ditelusuri pada prasejarah, yaitu serangkaian upaya-upaya orang pra sejarah untuk memitigasi atau menghindari bencana alam dengan adanya keberadaan guagua. Bahkan pembuatan kapal dalam masa Nabi Nuh sudah dapat dikegorikan sebagai manajemen bencana meskipun hanya fokus pada tanggap darurat bencana.

Dalam masa moderen, manajemen penanggulangan bencana, menurut beberapa literatur menunjukkan bahwa riset atau keterlibatan ilmu pengetahuan dalam penanggulangan bencana sudah dimulai sejak gempa bumi di Portugal tahun 1775 (Dynes, 200 dalam (Quarantelli, 1987). Pada tahun 1906, Wiliam James (dalam Lindell, 2011) sudah menggunakan metode riset yang sistematis. Berikutnya, perkembangan riset dalam manajemen bencana dicatat Quarantelli (Quarantelli, 1987) yaitu pada saat National Opinion Research Center/National Academy of Sciences tahun 1950 melakukan studi terhadap bencana alam misalnya Fritz and Marks (1954), Fritz (1961), Barton (1969) (Quarantelli, 1987). Riset bencana alam pada tahun 1950-an juga didokumentasikan Drabek (Drabek, 1985) dan Tierney (Tierney, 2005).

Pengertian umum ilmu pengelolaan bencana secara sederhana disebut sebagai "manajemen bencana". Kata manajemen ini merujuk pada kata "pengelolaan" dalam ilmu manajemen secara umum. Artinya bagaimana mengelola bancana agar lebih baik sehingga risiko menjadi lebih sedikit. Atau bisa berarti bagaimana mengelola kejadian bencana sejak perencanaan (sebelum bencana), tanggap darurat dan pasca bencana (Adiyoso, 2019). Sampai dengan saat ini masih sangat terbatas referensi yang membahas tentang apakah manajemen bancana itu sebuah ilmu yang berdiri sendiri atau "meminjam" dari ilmu lain, yaitu ilmu manajemen dan ilmu lainnya. Tulisan ini tidak akan membahas tentang eksistensi ilmu manajemen bancana sebagai ilmu sendiri atau bukan, tetapi akan fokus pada kontribusi ilmuilmu dalam manajemen bencana baik posisinya sebagai multidisiplin, interdisiplin atau transdisiplin (MIT).

Perkembangan riset dalam manajemen bencana yang sudah berkembang, sayangnya masih sedikit yang membahas tentang disiplin ilmu dalam manajemen bencana. Berbeda dengan ilmu-ilmu lain, pembahasan tentang pentingnya posisi sebuah ilmu apakah itu multidisplin, interdisiplin dan transdipslin dalam disiplin manajemen bencana masih terbatas (Stock \& Burton, 2011). Seperti diketahui bahwa tingkat kompleksitas suatu masalah memerlukan adanya upaya pemecahan masalah yang melibatkan berbagai disiplin ilmu (Sku \vcaiu \& Klein, 2010). Interaksi disiplin ilmu secara umum dapat dibedakan menjadi Interdisipliner (interdisciplinary), multidisipliner (multidisciplinary), interdisipliner (interdisciplinary) transdisipliner (transdisciplinary) dan krosdisipliner (crossdisiplinary). 
Dalam bidang lain, kolaborasi ini juga umum. Misalnya dalam ilmu kebijakan publik model dan desain partisipasi dikembangkan secara kolaboratif dengan tujuan untuk mengintegrasikan keilmuan dan administrasi serta aspek politik (Kristensen, Kyng, \& Palen, 2006 dalam (Noran, 2014)).

Pengertian multidisipliner adalah suatu upaya menggunakan berbagai disiplin ilmu yang relevan untuk memecahkan masalah (National Research Council, 2006). Menurut NRC (National Research Council, 2006) yang mengutip Klein "In multidisciplinary research, investigators representing different disciplines often work in parallel, rather than collaboratively. Multidisciplinary signifies the juxtaposition of disciplines. It is essentially additive, not integrative". Uwizeyimana dan Basheka (Uwizeyimana \& Basheka, 2017) mengartikan "additive" sebagai materi yang ditambahkan ke sesuatu dalam jumlah kecil untuk meningkatkan atau menjaga sesuatu itu sebagai produk hasil tambahan. Biasanya multidisiplin diartikan "ahli dari berbagai disiplin ilmu kerja bersama-sama secara independent pada beberapa aspek suatu proyek", sedangkan interdisiplin adalah "ahli dari berbagai disiplin ilmu kerja bersama-sama dalam suatu proyek” (Mallon and Burnton, S. 2005, dalam (Sku \vcaiu \& Klein, 2010).

Interdisipliner merujuk pada suatu pendekatan yang menggunakan berbagai sudut pandang ilmu dengan melakukan intgrasi metode dan analisis baik serumpun atau tidak untuk memecahkan suatu masalah (Ratnasiri, 2016), (Jessup, 2007). Menurut NRC (National Research Council, 2006) "the term interdisciplinary is used as an umbrella term to represent efforts usually conducted by research teams that involve ideas and methods from more than one discipline". Namun seringkali bahwa apa yang dimaksud "interdisiplin"” pada kenyataannya adalah "multidisiplin" (National Research Council, 2006). Menurut Ingham et al (Ingham et al., 2012) manajemen bencana akan lebih bagus dengan menggunakan pendekatan interdisiplin yang tidak hanya meningkatkan pengembangan pengelolaan bencana tetapi juga dapat mentransfer pengetahuan dari konsep kepada kebijakan dan praktek-praktek yang dikembangkan untuk tujuan pencegahan, tanggap darurat dan pasca bencana.

Sedangkan transdisipliner adalah usaha untuk membangun sebuah teori baru dengan mengembangkan kaitan dan relevansi antar berbagai disiplin ilmu. Mirip dengan interdispliner, pendekatan krosdisipliner ialah upaya untuk memecahkan suatu masalah dengan menggunakan tinjauan beberapa rumpun ilmu yang relevan. Pendekatan interdispliner dan krosdisipliner ini memungkinkan dua disiplin ilmu melebur menjadi satu ilmu. Gambar 1 dapat membantu menunjukkan simplifikasi perbedaan monodisiplin, multidisiplin, intradisiplin dan transdisiplin dalam manajemen bencana. 


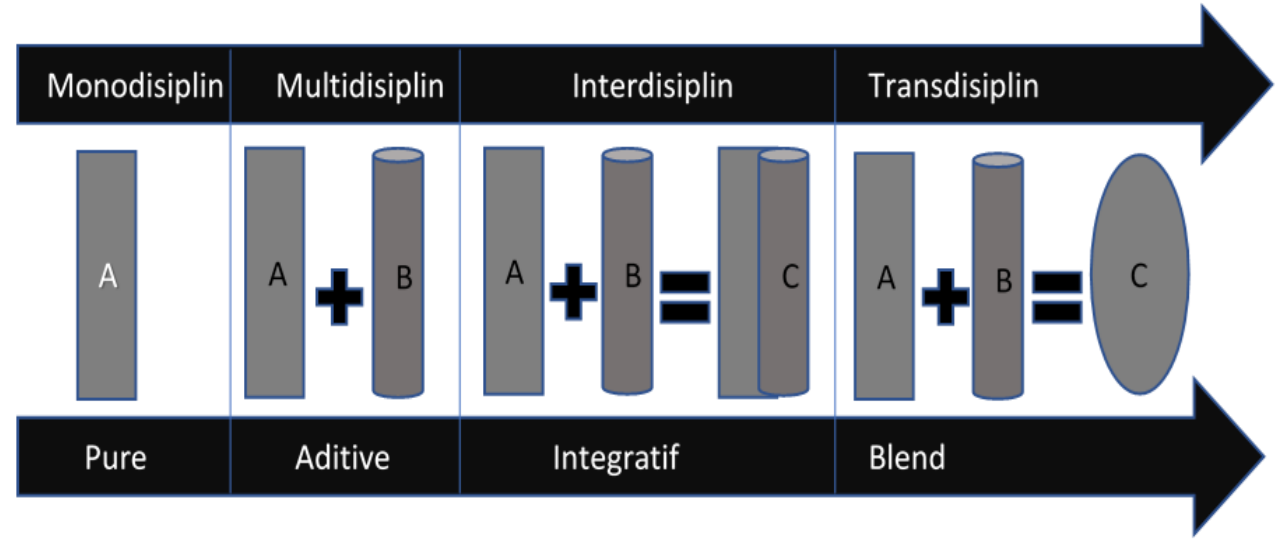

Gambar 1. Perbedaan Kolaborasi Disiplin Ilmu.

Adaptasi dari berbagai sumber.

Penelitian proyek penanggulangan bencana yang menggunakan interdisiplin diungkap oleh Faber at al (Faber et al., 2014) yang melakukan identifikasi keterlibatan ahli apa saja dalam suatu proyek penanggulangan bencana. Salah satu aspek temuan dalam penelitian interdisiplin pada proyek-proyek tingkat resiliensi penanggulangan bencana alam dari 5 disiplin ilmu yang paling banyak adalah geografi dan sosiologi (Faber et al., 2014).

Dari pembahasa liteatur di atas menunjukkan ada beberapa pilihan bagaimana disiplin ilmu memberikan kontribusi terhadap pengembangan diskursus menajemen bencana. Berbagai pilihan memiliki kelebihan dan kekurangan yang perlu dielaborasi lebih lanjut. Literatur juga menegaskan bahwa kolaborasi manajemen penanggulangan bencana sangat bermanfaat dalam manajemen penanggulangan bencana. Peran dan kontribusi disiplin ilmu tersebut bisa bersifat monodisiplin, interdisplin dan transdisiplin atau kombinasi.

\section{Diskusi dan Pembahasan}

Manajemen penanggulangan bencana di dunia telah mengalami beberapa perubahan paradigma yang dari sektoral menjadi multisektoral karena dengan beberapa alasan. Menurut Adiyoso (Adiyoso, 2019) pengurangan risiko secara multisektor bencana sangat penting karena bencana sangat kompleks dan melibatkan berbagai aktor. Selain itu bencana juga mengakibatkan dampak pada jiwa manusia, sosial, ekonomi, lingkungan dan infrastruktur. Dengan demikian maka penanganan bencana mulai dari mitigasi, kesiapsiagaan, tanggap darurat dan rehabilitasi dan rekonstruksi memerlukan berbagai disiplin ilmu. Dokumen perencanaan pembangunan nasional yaitu Rencana Pembangunan Jangka Menengah (RPJMN) 2020-2024 secara nyata mendukung adanya integrasi penanganan bencana (Peraturan Presiden No. 18 Tahun 2020 Tentang Rencana Pembangunan Jangka Menengah (RPJMN) 2020-2024, 2020).

Sebelum membahas bagaimana hubungn ilmu-ilmu pengetahuan dalam mendukung manajemen bencana, maka perlu digambarkan tentang kajian atau penelitian tentang peran 
ilmu pengetahuan dalam penanggulangan bencana. Dengan menggunakan analisa bibliometrika tentang manajemen bencana, ilmu (science) dan disiplin (disciplinary) dapat mengetahui perkembangan penelitian keilmuan manajemen bencana dalam terbitan ilmiah. Pada gambar 2 menunjukkan hasil analisa bibliometrika dengan menggunakan mesin pencairan kombinasi kata kunci "disaster AND science AND disciplinary OR multidisciplinary OR study' di google schoolar (GS). Dari gambar secara umum menggambarkan penelitian bencana dalam konteks disiplin ilmu bahwa ada tema-tema keilmuan yang menonjol seperti journal, framework, university, institute, Jepang, technology, article, international journal, dan disaster risk reduction. Istialh-istilah ini menunjukkan tanda-tanda korelasi antara bencana dan keilmuan. Sedangkan dari pengelompokan teman-tema istilah ada enam klaster yaitu "international journal” (ungu), "framework" (merah), "disaster risk reduction” (kuning tua), "institute” (biru tua), technoly (hihau) dan "journal” (biru muda).

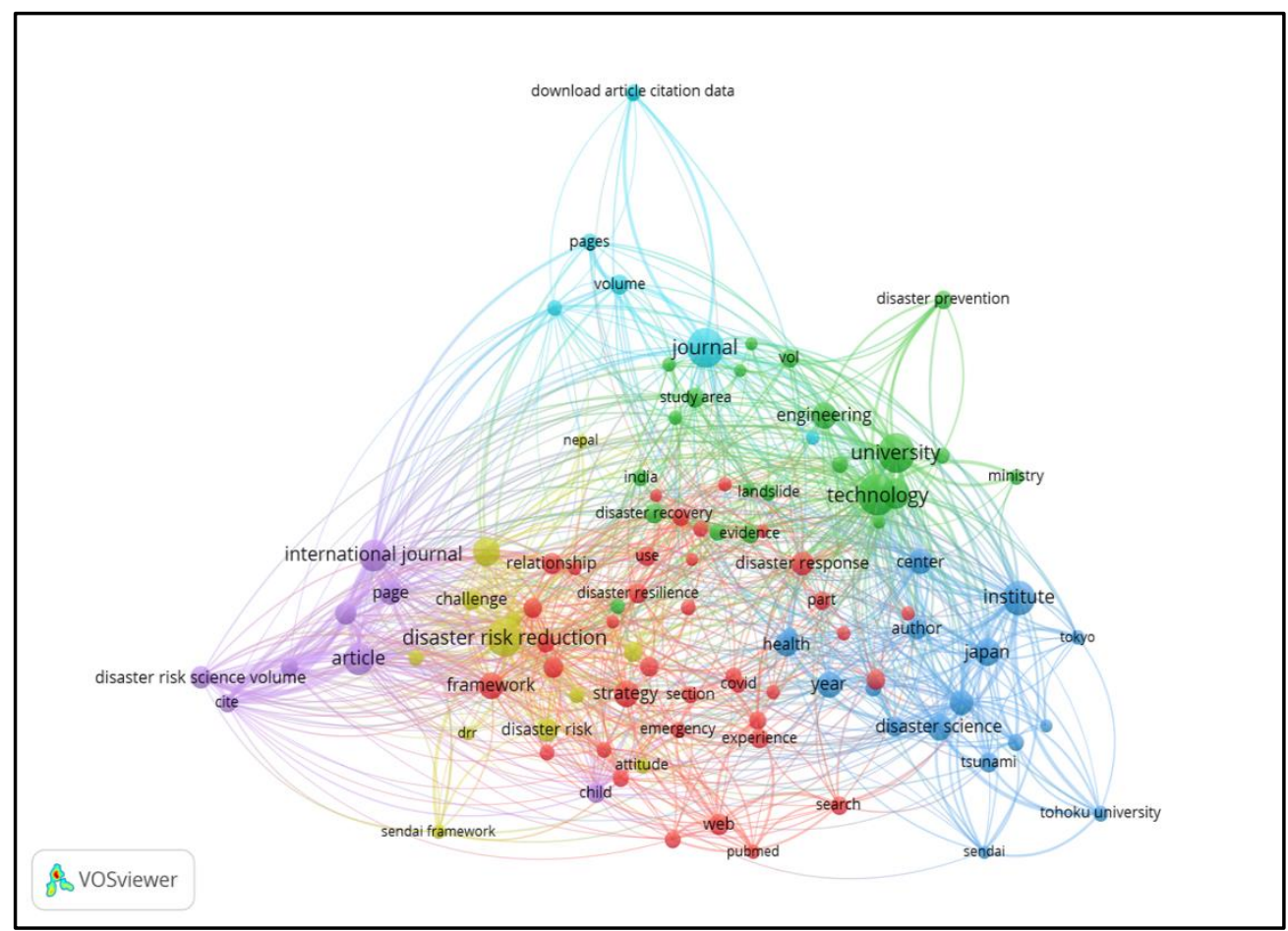

Gambar 2. Visualisasi Penelitian tentang Disiplin Ilmu dan Manajemen Bencana

Dari hasil visualisasi menunjukkan bahwa istilah-istilah masih menggunakan konsep bencana secara umum, belum menggunakan istilah spesifik dalam disiplin ilmu misalnya komunikasi, geologi, vulkonologi, sosiologi, kesehatan, psikologi dan lainnya. Menariknya gambar ini juga tidak konsisten dengan hasil studi yang dilaksanakan oleh Faber (Faber et al., 2014) bahwa istilah geografi dan sosiologi paling banyak ditemukan dalam kajian disiplin ilmu dalam penanggulangn bencana. Dengan sedikitnya kemunculan jenis-jenis dalam visualisasi kemungkinan besar studi tentang disiplin ilmu bencana masih terbatas pada jenis bahaya yang muncul seperti tsunami (biru tua) dan landslide (biru tua). 
Hal yang menarik dari visualsiasi juga hanya memunculkan tiga negara yang melakukan kajian tentang hubungan bencana dan disiplin ilmu.

Keterhubungan antara bencana dan displin ilmu, selain dari munculnya tema dalam kajian, juga dapat dilihat dari aspek siklus manajemen bencana. Dalam siklus manajemen bencana, tahap awal adalah melakukan identifikasi dan penilaian (risk assessment) terhadap seluruh jenis ancaman yang memiliki risiko menjadi bencana. Dalam tahap ini saja sudah melibatkan berbagai disiplin ilmu. Karena di dalam fase risk assesment, harus didentifikasi seluruh jenis ancaman. Oleh karena itu peran dan kontribusi ilmu seperti geologi (gempa), antropologi (tsunami), morfologi tanah (tanah longsor), kelautan (tsunami), cuaca (banjir), seismologi (gempa), geodesi (tsunami dan banjir) dan lain-lain.

Salah satu contoh riset multidiplin tetapi juga mirip dengan interdisiplin adalah penyusunan dan penyempurnaan peta zonasi gempa 2017. Dalam menyusun peta ini telah melibatkan beberapa keahlian yaitu geologi, geodesi, seismologi, ground motion prediction equation (GMPE) dan seismic hazard analisis (SHA) (Tim Pusat Studi Gempa Nasional, 2017). Ahli geologi, sebagai contoh, bertugas menghasilkan input parameter gempa berdasarkan geomorfologi. Ahli geologi memastikan "lokasi sumber gempa, kinematika gerak, kejadian gempa terakhir, dan periode ulang” (Tim Pusat Studi Gempa Nasional, 2017). Ahli seismologi menentukan parameter seismisitas pada sumber gempa. Sedangkan ahli geodesi memberikan informasi tentang kecepatan dalam zona subduksi. Sedangkan ahli GMPE memberikan analisis tentang bahaya gempa didasarkan pada kesamaan kondisi geologi dan tektoknik. Terakhir, ahli analisis bahasa seistimik memberikan masukan terhadap bahaya goncangan yang diakibatkan oleh gempa. Dari hasil berbagai displin ilmu tersebut terbit peta zonasi sumber gempa yang menyatu dan digunakan sebagai acuan untuk peta kegempaan.

Dalam fase risk assessment ini juga dilakukan identifikasi dan penilaian terhadap kerentanan dan kapasitas yang terdiri dari fisik, sosial, ekonomi, dan lingkungan. Untuk melakukan penilaian kerentanan dan kapasitas ini saja, juga diperlukan peran disiplin ilmu lingkungan hidup yang terdiri dari ilmu kimia, ilmu sumber daya air, lingkungan, fisika, matematika dan lainnya. Sedangkan kerentanan dan kapasitas sosial pasti membutuhkan ilmu-ilmu seperti psikologi, komunikasi, antropologi, sosiologi, agama, statistik dan lainnya.

Begitu juga dalam fase berikutnya dalam siklus manajemen bencana. Dalam beberapa literatur setelah dilakukan risk assessment, maka dilakukan penyusunan kebijakan penanggulangan bencana. Dalam penyusunan kebijakan bencana ini adalah bagaimana strategi, langkah-langkah, prosedur, program dan kegiatan yang akan dilakukan dalam rangka mengurangi ancaman yang sudah diidentifikasi. Dalam menyusun rencana penanggulangan bencana misalnya berbagai disiplin ilmu diperlukan seperti kebijakan publik, manajemen, keuangan, sosiologi, komunikasi dan lainnya.

Salah satu contoh bagaimana kesiapsiagaan bencana dilakukan dengan berbagai macam disiplin ilmu telah dilakukan di New Zealand. Ronan et al (2000), melakukan penelitin menggunakan pendekatan sosial dan teknik (vulcanologist). Penelitian ini menggabungkan pengetahuan tentang sumber, pergerakan, dampak dan debu letusan gunung berapi digabungkan dengan sosial ekonomi masyarakat serta komunikasi risiko masyarakat bagaimana menghadapi ancaman gunung berapi. 
Gambar 3 dapat menjelaskan beberapa praktek yang yang telah dan seharusnya dilakukan dalam rangka penanggulangan letusan gunung Merapi sebagai konsep yang telah dilakukan di New Zealand. Namun demikian perlu dicatat, bahwa model penanganan ini tidak hanya dilakukan pada saat gunung api meletus, namun demikian sejak penyusunan perencanaan hingga implementasi dilakukan secara bersama-sama.

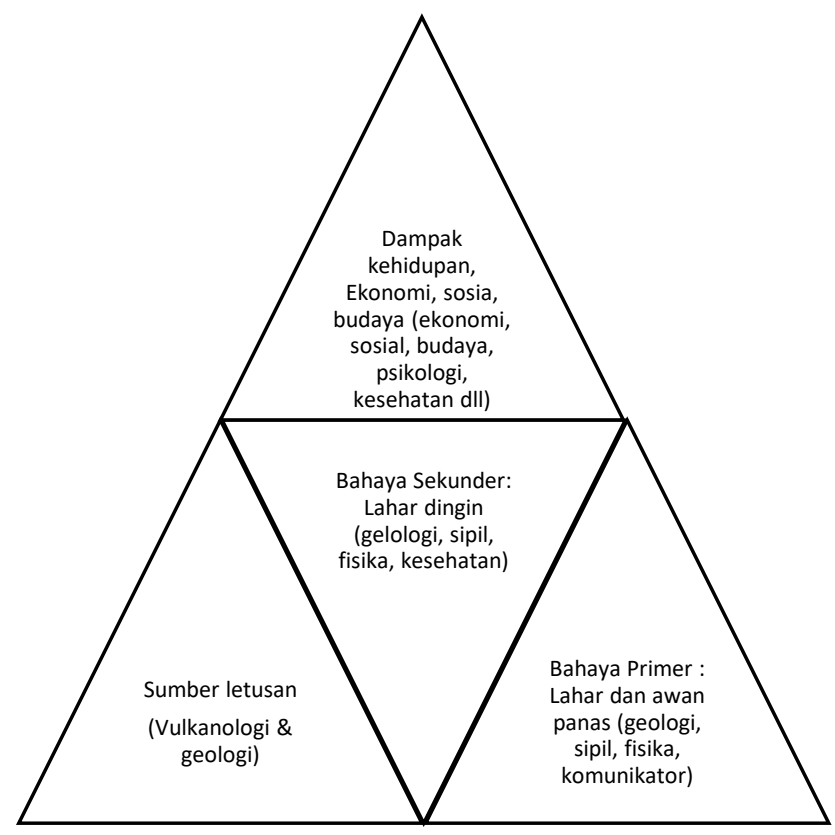

Gambar 3. Multidisiplin Ilmu dalam Penanggulangan Letusan Gunung Berapi

Kontribusi berbagai disiplin ilmu dalam manajemen bancana juga jelas pada tahap tanggap darurat. Pada fase tanggap darurat ini, mamang biasanya banyak penelitian fokus pada psikologi. Pada situasi tanggap darurat, orang merespon suatu kejadian bencana dengan kepanikan akibat tekanan mental. Tindakan orang-orang terdampak kemudian menjadi sentral penelitian menajemen bencana. Dalam fase tanggap darurat, ada berbagai disiplin ilmu yang dapat membantu menjelaskan pesoalan tanggap darurat sehingga dapat menyelamatkan banyak jiwa. Salah satu contohnya adalah pelibatan berbagai disiplin ilmu dalam fase tanggap darurat yang terjadi di Nepal. Pendekatan distribusi logistik bantuan pada tanggap darurat korban gempa di Nepal dikaji dari disiplin sosial dan teknis sehingga menjadikan para korban bangkit kembali kehidupannya (Baharmand et al., 2016). Dengan menggabungkan berbagai disiplin ilmu ini, maka kompleksitas masalah tanggap darurat dalam suatu peristiwa bencana dapat memberikan peta masalah yang lebih mendekati atau sesuai dengan kenyataan yang dialami masyarakat.

Pada siklus akhir manajemen bencana, yaitu rehabilitasi dan rekonstruksi diperlukan peran berbagai disiplin ilmu untuk memperbaiki tata kelola pasca bencana. Beberapa area yang menjadi fokus ada pasca bencana adalah dampak mental (psikologi), hubungan antar individu dan masyarakat (sosial), teralineasi (politik), aspirasi (kebijakan publik), komunikasi, penghasilan (ekonomi), pendidikan, ibadah serta hal-hal teknis pelayanan makan, hunian dan pakaian seperti penggunaan bahan untuk penampungan 
pengungsi sementara, jenis makanan yang cocok bagi pengungsi, jenis pakaian bagi pengungsi, tata letak pengungsian dan lainnya.

Survey di 20 negara Eropa dengan melibatkan 57 responden yang dilakukan oleh sekelompok ahli (Faber et al., 2014) yang meneliti tentang resiliensi mengungkapkan bahwa telah melibatkan 5 disiplin ilmu dengan pendekatan interdispliner termasuk sosial, kultural, pendidikan, perkotaan, geografi, dan sosiologi. Mereka menyimpulkan bahwa kolaborasi tersebut dapat meningkatkan efikasi dan kualitas desain resiliensi. "The establishment of an education on resilient design of urban system, which includes both social and technological aspects, emerges as a possible solution to overcome barriers to interdisciplinary work and improve the efficacy and quality of resilience design" (Faber et al., 2014).

Dari hasil diskusi di atas menunjukkan peran dan konribusi disiplin ilmu dalam siklus manajamen bencana sejak pra bencana, saat bencana dan pasca bencana. Hal ini juga memperkuat pendapat bahwa dalam manajemen bencana berbagai macam ilmu diperlukan dalam rangka memecahkan solusi atas ancaman dan dampak bencana serta kompleksitas masalah yang melingkupinya. Hasil Analisa literaturu dan paktek baik menunjukkan bahwa kolaborasi atau kerja sama dari berbagai disiplin ilmu dalam pengelolaan bencana dapat meningkatan efektivitas dan membantu menyelesaikan masalah-masalah pengelolaan bencana dalam seperti monodisiplin, intradisiplin, transdisiplin dan lainnya.

\section{Kesimpulan dan rekomendasi}

Dengan intensitas dan dampak kejadian ancaman bahaya yang semakin sering dan tinggi maka diperlukan manajemen penanggulangan bencana untuk menyelamatkan jiwa dan harta benda manusia. Ilmu atau pendekatan manajemen bencana melibatkan dan memerlukan berbagai disiplin ilmu guna meningkatkan efektivitas penanggulangan bencana. Meskipun berbagai disiplin ilmu telah fokus meneliti fenomena bencana, namun posisi dan hubungan antara berbagai disiplin tersebut perlu diperjas ke dalam siklus manajemen bencana sebelum, pada saat dan setelah bencana.

Dari contoh-contoh kasus dan diskusi di atas, telah jelas bahwa berbagai displin ilmu telah memberikan kontribusi terhadap penyelesaian masalah dalam manajemena bencana secara terpadu meskipun kebanyakan adalah multidiplin. Dalam penyusunan informasi kegempaan di Indonesia, berbagai disiplin ilmu bersatu menyusun peta gempa seperti geologi, geodesi, GMPE, SHA, dan seismologi. Di New Zealand, efektivitas penanggulangan bencana berjalan dengan baik setelah adanya kolaborasi antara ilmu sosial dan teknik. Berbagai disiplin ilmu juga digunakan dalam rangka menganalisis akurasi pendistribusian logistik ketika gempa Nepal terjadi.

Dengan kerja sama berbagai disiplin ilmu maka penanggulangan bencana diharapkan lebih efektif. Tulisan ini adalah tahap awal sebuah kajian sehingga penelitian lanjutan dan pendalaman diperlukan seperti kajian tentang apakah ilmu manajemen bencana sebagai sebuah ilmu sendiri. Penelitian lainnya yang penting adalah model kolaborasi yang mana yang paling efektif apakah multidisiplin, intradisiplin, dan transdisiplin. Artikel diharapkan dapat mendorong para peneliti, akademisi, pembuat kebijakan, pengelola risiko dan para pelaku penanggulangan bencana melanjutkan penelitian lebih lanjut. 


\section{Daftar Pustaka}

Adiyoso, W. (2019). Manajemen Bencana: Isu-isu Strategis (1st ed.). Bumi Aksara. http://opac.lib.ugm.ac.id/index.php?mod=book_detail\&sub=BookDetail\&act=view \&typ=htmlext\&buku_id=782902\&obyek_id=1

Aitsi-Selmi, A., Blanchard, K., Al-Khudhairy, D., Ammann, W., Basabe, P., Johnston, D., Ogallo, L., Renn, O. T., Revi A, Roth C, Schneider, P. S., Wenger, J., \& Murray V. (2015). Science Used for Disaster Risk Reduction. In UNISDR STAG 2015 Report: Science is used for disaster risk reduction. http:// preventionweb.net/go/42848

Baharmand, H., Boersma, K., Meesters, K., Mulder, F., \& Wolbers, J. (2016). A multidisciplinary perspective on supporting community disaster resilience in Nepal. Proceedings of the International ISCRAM Conference, May 2016, 1-11.

Bengtsson, M. (2016). How to plan and perform a qualitative study using content analysis. NursingPlus Open, 2, 8-14. https://doi.org/10.1016/j.npls.2016.01.001

BNPB. (2019). Data Informasi Bencana Indonesia. https://dibi.bnpb.go.id

Damon P. Coppola. (2017). Introduction to International Disaster Management. Elsevier Inc.

Drabek, T. E. (1985). Managing Disaster Management Response. Public Administration Review, Special Issue.

Faber, M. H., Giuliani, L., Revez, A., Jayasena, S., Sparf, J., \& Mendez, J. M. (2014). Interdisciplinary Approach to Disaster Resilience Education and Research. Procedia Economics and Finance, 18(September), 601-609. https://doi.org/10.1016/s22125671(14)00981-2

Feehan, J., \& Apostolopoulos, V. (2021). Is COVID-19 the worst pandemic? Maturitas, 149(January), 56-58. https://doi.org/10.1016/j.maturitas.2021.02.001

Ingham, V., Hicks, J., Islam, M. R., Manock, I., \& Sappey, R. (2012). An interdisciplinary approach to disaster management, incorporating economics and social psychology. International Journal of Interdisciplinary Social Sciences, 6(5), 93-106. https://doi.org/10.18848/1833-1882/CGP/v06io5/52074

Jessup, R. L. (2007). Interdisciplinary versus multidisciplinary care teams: do we understand the difference? Australian Health Review: A Publication of the Australian Hospital Association, 31(3), 330-331. https://doi.org/10.1071/ah070330

National Research Council. (2006). Interdisciplinary Hazards and Disaster Research. In Facing Hazards and Disasters: Understanding Human Dimensions (pp. 180-215). The National Academies Press. https://doi.org/10.17226/11671

Noran, O. (2014). Collaborative disaster management: An interdisciplinary approach. $\begin{array}{llll}\text { Computers in } \quad \text { Industry, } & \text { 65(6), }\end{array}$ https://doi.org/https://doi.org/10.1016/j.compind.2014.04.003

Peraturan Presiden No. 18 Tahun 2020 tentang Rencana Pembangunan Jangka Menengah (RPJMN) 2020-2024, (2020) (testimony of Peraturan Presiden No. 18/2020).

Quarantelli, E. L. (1987). Disaster studies: an analysis of the social historical factors affecting the developmenbt of reseach in the area. International Journal of Mass Emergencis and Disaster, 5(3), 285-310. https://doi.org/10.1177/0011392113484456

Ratnasiri, N. (2016). Interdisciplinarity and multidisciplinarity in research. Journal of the National Science Foundation of Sri Lanka, 44(1), 1-2. https://doi.org/10.4038/jnsfsr.v44i1 1.7975

Robinson, K. R. (2021). Comparing the Spanish flu and COVID-19 pandemics: Lessons to 
carry forward. Nursing Forum, 56(2), 350-357. https://doi.org/10.1111/nuf.12534

Sku \vcaiu, A., \& Klein, J. (2010). Interdisciplinary Research-challenges and Opportunities for Actuarial Profession.

Stock, P., \& Burton, R. J. F. (2011). Defining terms for integrated (multi-inter-transdisciplinary) sustainability research. Sustainability, 3(8), 1090-1113. https://doi.org/10.3390/su3081090

Tierney, K. (2005). Effective Strategies for Hazard Assessment and Loss Reduction: The Importance of Multidisciplinary and Interdisciplinary Approaches. Natural Hazards Research and Applications Information Center, Institute of Behavioral Science, University of Colorado, Boulder CO, 1-20.

Tim Pusat Studi Gempa Nasional. (2017). Peta Sumber Dan Bahaya Gempa Indonesia Tahun 2017. In Pusat Penelitian dan Pengembangan Perumahan Pemukiman, Badan Penelitian dan Pengembangan Kementerian Pekerjaan Umum dan Perumahan Rakyat. Pusat Penelitian dan Pengembangan Perumahan dan Permukiman, PUPR.

Uwizeyimana, D., \& Basheka, B. (2017). The Multidisciplinary, Interdisciplinary Nature of Public Administration: A Methodological Challenge? African Journal of Public Affairs, $9(9), 1-28$.

WHO. (2021). COVID-19 vaccines. https://www.who.int/emergencies/diseases/novel-coronavirus-2019/covid-19vaccines 